\title{
FACTORS ASSOCIATED WITH OPEN DEFECATION IN FLOOD-PRONE AREAS IN INDONESIA
}

\author{
Sri Irianti'), Rr. Rachmalina Soerachman'1), \\ Zahra Zahra'), Puguh Prasetyoputra' ${ }^{2)}$ \\ 1)National Institute of Health Research and Development, Ministry of Health, Jakarta \\ ${ }^{2}$ Research Center for Population, Indonesian Institute of Sciences, Jakarta
}

\begin{abstract}
Background: Open defecation (OD) is the human practice of defecating outside (in the open environment) rather than into a toilet. This practice is still happening in some countries, especially in low- and middle-income countries (LMIC). Natural disaster can happened to worsen the OD practice. There is still no study that eligible to the association of natural disaster and OD practice. This study aimed to determine the factors associated with open defecation in flood-prone areas in Indonesia.

Subjects and Methods: This was an observational study. The data were obtained from Basic Health Research (Riskesdas) and National Socio-Economic Survey (Susenas), in 2013. OD practice and socio-demographic characteristics of the households were obtained from Riskesdas in 2013. Flood experience of the households was obtained from Susenas in 2013. The data were analyzed by multivariate logistic regression and odds ratio (OR) as the measure of association.

Results: Out of 835,256 people, $18.93 \%$ reported defecation in an open environment. The OD prevalence was higher in the rural areas (28.61\%) than in the urban areas (7.48\%). People lived in flood-prone area was more likely to practice $\mathrm{OD}(\mathrm{OR}=1.85$; $95 \% \mathrm{CI}=1.81$ to $1.89 ; \mathrm{p}<0.001)$ than those who lived in non-flood-prone area. Access to drinking water, sanitation facility, and household socioeconomic status were also found to be significantly associated with OD practice.

Conclusion: Open defecation (OD) practice in the rural area is higher than in the urban area. People lived in flood-prone area is more likely to practice OD. Access to drinking water, sanitation facility, and household socioeconomic status are associated with OD practice.
\end{abstract}

Keywords: open defecation, flood-prone area, rural, urban, Indonesia

\section{Correspondence:}

Sri Irianti. National Institute of Health Research and Development, Ministry of Health, Indonesia, Jl. Percetakan Negara No. 29, Jakarta 10560, Indonesia. Email: iriantis@gmail.com. Mobile: o8129696133. 